\title{
Virulence Characteristics Accounting for Fire Blight Disease Severity in Apple Trees and Seedlings
}

\author{
Steven A. Lee, Henry K. Ngugi, Noemi O. Halbrendt, Grace O’Keefe, Brian Lehman, \\ James W. Travis, Judith P. Sinn, and Timothy W. McNellis
}

First, second, fifth, sixth, seventh, and eighth authors: Department of Plant Pathology, The Pennsylvania State University, University Park 16802; second, third, fifth, and sixth authors: The Pennsylvania State University Fruit Research and Extension Center, Biglerville 17307; and fourth author: United States Department of Agriculture, Animal and Plant Health Inspection Service, Plant Protection and Quarantine, The Pennsylvania State University, University Park 16802.

Accepted for publication 25 January 2010.

\begin{abstract}
Lee, S. A., Ngugi, H. K., Halbrendt, N. O., O'Keefe, G., Lehman, B., Travis, J. W., Sinn, J. P., and McNellis, T. W. 2010. Virulence characteristics accounting for fire blight disease severity in apple trees and seedlings. Phytopathology 100:539-550.

The gram-negative bacterium Erwinia amylovora is the causal agent of fire blight, the most destructive bacterial disease of rosaceous plants, including apple and pear. Here, we compared the virulence levels of six E. amylovora strains (Ea273, CFBP1367, Ea581a, E2002a, E4001a, and HKN06P1) on apple trees and seedlings. The strains produced a range of disease severity, with HKN06P1 producing the greatest disease severity in every assay. We then compared virulence characteristic expression among the six strains, including growth rates in immature apple fruit, amylovoran production, levansucrase activity, biofilm formation, carbohydrate
\end{abstract}

ABSTRACT utilization, hypersensitive cell death elicitation in tobacco leaves, and protein secretion profiles. Multiple regression analysis indicated that three of the virulence characteristics (amylovoran production, biofilm formation, and growth in immature apple fruit) accounted for $>70 \%$ of the variation in disease severity on apple seedlings. Furthermore, in greenhouse-grown 'Gala' trees, $>75 \%$ of the variation in disease severity was accounted for by five of the virulence characteristics: amylovoran production, biofilm formation, growth in immature apple fruit, hypersensitive cell death elicitation, and sorbitol utilization. This study demonstrates that virulence factor expression levels account for differences in disease severity caused by wild isolates of E. amylovora on apple trees.

Additional keywords: disease incidence, DspA/E, HrpN, hypersensitive reaction, pCPP60, pEA29, type III secretion.
Fire blight has been known for centuries as a devastating disease of many plants in the family Roseaceae, including economically important species such as apple, pear, and raspberry $(22,64)$. Fire blight is caused by the bacterium Erwinia amylovora $(3,17,64)$. Fire blight has a complex disease cycle and is difficult to manage $(33,52,59)$. Control measures include application of antibiotic and copper sprays based on disease forecasting models, pruning of infected branches, biological control, and use of fireblight-tolerant rootstocks and cultivars $(33,56)$.

Pathogenicity in E. amylovora has been well studied and several key factors have been identified $(23,54)$. One critical factor essential for pathogenesis is the production of extracellular polysaccharides $(7,11,63)$. For example, amylovoran is a major component of the ooze produced by E. amylovora (8) and contributes to bacterial movement in planta (15).

Carbohydrate utilization is another important component of $E$. amylovora pathogenicity (28). Sorbitol and sucrose are the two major forms of transported and stored carbohydrates in rosaceous plants $(19,66)$. In E. amylovora, mutations in the sorbitol ( $\mathrm{srl}$ ) operon disrupt pathogenicity in apple seedlings (2), while $E$. amylovora mutants unable to metabolize sucrose have reduced virulence in apple seedlings (15).

Nonchromosomal DNA elements also play a role in E. amylovora virulence. With few exceptions, E. amylovora strains isolated from nature contain a stable, nontransmissible plasmid called pEA29 $(24,39,41,43)$. Fire blight disease incidence and

Corresponding author: T.W. McNellis; E-mail address: twm4@psu.edu

doi:10.1094/PHYTO-100-6-0539

(C) 2010 The American Phytopathological Society symptom development is reduced with strains cured of pEA29 $(24,39,43)$. However, the role of pEA29 in E. amylovora virulence has not been fully described.

Another essential factor for pathogenesis and virulence of $E$. amylovora is the bacterial type III secretion system (T3SS) (31). The T3SS secretes and translocates bacterial proteins into host cells (30). E. amylovora secretes several proteins via the T3SS that contribute to pathogenicity, virulence, and avirulence, including HrpN, DspA/E, HrpJ, and AvrRpt2 $2_{\text {EA }}(13,14,27,67,69)$.

E. amylovora appears to be a fairly homogeneous species $(12,65)$. Early studies $(12,37)$ using biochemical analyses revealed a high degree of phenotypic similarity between $E$. amylovora strains, even when strains from different geographical regions were compared (45). However, more recent studies using molecular fingerprinting techniques such as repetitive polymerase chain reaction (PCR) and ribotyping, random amplified polymorphic DNA analysis, and restriction fragment length polymorphisms have shown that diversity exists among E. amylovora strains $(44,46,68)$. In fact, these studies resulted in the development of three major classifications of E. amylovora strains: Maloideae, Rubus, and 'Hokkaido' (45). In addition, variations in aggressiveness among strains of E. amylovora have been observed (18).

Although pathogenicity can be defined as the overall ability of an organism to infect a host and cause disease, virulence is the severity of disease caused by a pathogen (60). The objective of this work was to determine whether expression levels of virulence characteristics account for variations in disease severity caused by different, natural E. amylovora strains. The E. amylovora strains selected provided a range of disease severity and included Ea273, Ea581a, CFBP1367, E2002a, E4001a, and HKN06P1. Ea273 is a 
highly virulent strain for which the complete genomic sequence is available (http://www.sanger.ac.uk/Projects/Microbes/); CFBP1367 is a moderately virulent strain that has been used extensively for virulence analysis; Ea581a is a moderately virulent strain that has been used extensively by our research group; E2002a and E4001a are highly virulent isolates $(48,49,51)$; and HKN06P1 is a new, highly virulent isolate from Pennsylvania.

\section{MATERIALS AND METHODS}

Isolation of $\boldsymbol{E}$. amylovora strain HKN06P1. Strain HKN06P1 was isolated in 2006 from a diseased, 1-year-old 'Golden Delicious' tree with an EMLA 26 rootstock submitted by a grower for testing at the Penn State Fruit Research and Extension Center in Biglerville, PA. A single-colony isolate of the strain was obtained by streaking fresh bacterial ooze from symptomatic shoot tissue on modified Lennox agar medium (15.0 g of Lennox broth agar, $15.5 \mathrm{~g}$ of nutrient agar, $10 \mathrm{ml}$ of glycerol, and $4.0 \mathrm{~g}$ of $\mathrm{NaCl}$ per liter, $\mathrm{pH}$ 7) in $10-\mathrm{mm}$ petri plates. The plates were incubated at $28^{\circ} \mathrm{C}$ and the bacterial culture purified through two steps of single-colony subculturing before being subjected to pathogenicity tests. Pathogenicity tests were carried out with immature fruit and apical shoot inoculation tests as described below. The identity of the isolate was confirmed by PCR using $E$. amylovora-specific primers and protocol described by Bereswill et al. (10).

Bacterial strains. Bacterial strains used in this study are described in Table 1. Bacterial cultures were stored in Luria-Bertani (LB) liquid media containing $20 \%$ glycerol at $-80^{\circ} \mathrm{C}$. Fresh, overnight cultures grown on LB agar or modified Lennox medium were used for all experiments. Bacterial suspensions used for inoculations were made by flooding plates with media or buffer and agitating slowly for 5 to $10 \mathrm{~min}$.

Plant material. For controlled environment assays, apple seed from open-pollinated 'Gala' plants were stratified in sterile, wet sand for 6 to 8 weeks at $4^{\circ} \mathrm{C}$ until germination. Germinating seed were transferred to soil and grown for 6 months at $22^{\circ} \mathrm{C}$ with $75 \%$ relative humidity under light at $100 \mu \mathrm{mol} \mathrm{m}^{-2} \mathrm{~s}^{-1}$ for $16 \mathrm{~h} \mathrm{day}^{-1}$. Ungrafted 'Gala' trees were produced in tissue culture and transferred to soil and grown under similar conditions to the seedlings. 'Gala' trees on Bud.9 rootstocks were grown in a greenhouse.

Inoculation and disease assessment. Apple seedlings and 3-year-old field-grown 'Gala' trees on M.27 rootstocks were inoculated as previously described with slight modification (32). Newly opened leaves of young and succulent shoots were inoculated by bisecting across the leaves, including the midrib, with sharp scissors dipped in the inoculum. The E. amylovora inoculum was adjusted to a concentration of $1 \times 10^{8} \mathrm{CFU} \mathrm{ml}{ }^{-1}$. Disease severity was determined by measuring the length of shoot necrosis divided by the total shoot length and expressed as a percent. Necrotic lesions were measured at 7 and 15 days postinoculation (dpi) in field experiments and at 15 dpi in seedling assays.

TABLE 1. Bacterial strains used in this work

\begin{tabular}{lll}
\hline Bacterial strain & Host and origin & Source, reference \\
\hline $\begin{array}{l}\text { Erwinia amylovora } \\
\text { Ea273 }\end{array}$ & Malus, NY & 62 \\
Ea581a & Malus, PA & 32 \\
CFBP1367 & Crataegus, France & 62, INRA, France \\
HKN06P1 & Malus, PA & This work \\
E2002a ${ }^{\text {b }}$ & Malus, Canada & 49,57 \\
E4001a & Pyrus, Canada & 49,57 \\
Dickeya dadantii & & \\
Lab isolate by G. O'Keefe & Phalaenopsis, Taiwan & This work \\
\hline
\end{tabular}

${ }^{a}$ http://www-intranet.angrs.inra.fr/cfbp/catalogue.htm.

b Referred to as Ea265 (49).

c Referred to as Ea266 (49).
For field-grown tree inoculations, five replicate trees were inoculated with Ea581a or HKN06P1. Five shoots were inoculated per tree. Necrosis was measured for each shoot. A $t$ test was used to determine significant differences between disease severity caused by HKN06P1 and Ea581a $(\alpha=0.05)$. Apple seedling inoculations contained four replicate trees inoculated with HKN06P1, Ea273, Ea581a, or CFBP1367 (Table 1). One-way analysis of variance (ANOVA) and Tukey's honestly significant difference (HSD) were used to determine separation of means $(\alpha=0.05)$. Field inoculations and seedling assays were conducted three times.

For greenhouse tree inoculations, four replicate trees were inoculated with E. amylovora strains HKN06P1, Ea273, Ea581a, CFBP1367, E2002a, or E4001a. Four shoots were inoculated per tree. The length of the necrotic region was measured for each shoot. One-way ANOVA and Tukey's HSD were used to determine separation of means $(\alpha=0.05)$.

Avirulence assays. Avirulence assays were carried out with potted tobacco plants. Tobacco is a nonhost plant for E. amylovora that is often used to assess E. amylovora hypersensitive response on tobacco $(4,7,67)$. Tobacco plants (Nicotiana tabacum L. cv. Glurk) were grown as previously described (61). Approximately 6 weeks after planting, leaves were infiltrated with $E$. amylovora strains. E. amylovora strains were grown overnight in LB media, pelleted by centrifugation, and washed with $1 \times$ phosphate-buffered saline (PBS) buffer before diluting to a series of bacterial concentrations ranging from $1 \times 10^{5}$ to $1 \times 10^{8} \mathrm{CFU} \mathrm{ml}{ }^{-1}$. After infiltration using a needleless syringe, plants were returned to their normal growing conditions. Hypersensitive responses were assessed $24 \mathrm{~h}$ later. The experiment was performed three times.

Relative ion leakage assays were also carried out with potted tobacco plants. Each E. amylovora strain was infiltrated into one leaf of three tobacco plants at a concentration of $1 \times 10^{7} \mathrm{CFU} \mathrm{ml}{ }^{-1}$. Samples were taken at $18 \mathrm{~h}$ after infiltration. Each sample contained four leaf disks excised from infiltrated leaves using a number 8 cork borer and immersed in a glass beaker containing $50 \mathrm{ml}$ of distilled water for $4 \mathrm{~h}$ at $28^{\circ} \mathrm{C}$ with gentle agitation. Conductivity was measured using a Traceable conductivity meter (Control Company, Friendswood, TX). Samples were autoclaved and conductance was remeasured. Relative ion leakage was determined by dividing conductivity before autoclaving by the conductivity after autoclaving, multiplied by 100 to produce a percentage. Relative ion leakage experiments were performed three times.

Virulence assays on immature fruit. Immature 'Gala' apple fruit were surface disinfested by immersion in a $1 \%$ sodium hypochlorite solution for $2 \mathrm{~min}$, rinsed with distilled water twice, and allowed to air dry in a laminar hood. Fruit were halved and placed cut side down on moist filter paper inside a petri dish. Each fruit was wounded twice with a sterilized 16-penny nail and inoculated with $10 \mu \mathrm{l}$ of a $1 \times 10^{8} \mathrm{CFU} \mathrm{ml}{ }^{-1}$ bacterial suspension into each wound. Inoculated fruit were maintained on wet filter paper in unsealed petri dishes in a growth chamber $\left(26^{\circ} \mathrm{C}, 75 \%\right.$ relative humidity, light at $90 \mu \mathrm{mol} \mathrm{m} \mathrm{m}^{-2} \mathrm{~s}^{-1}$ for $10 \mathrm{~h} \mathrm{day}^{-1}$ ). Disease incidence was scored as the first emergence of bacterial ooze from the lenticels of the fruit. Fruit were assessed for incidence on a daily basis. Each strain was inoculated on 25 apple halves from different fruit and experiments were conducted three times. Control, mock-inoculated $(1 \times$ PBS $)$ fruit were included in each experiment.

For quantitative bacterial growth determination, fruit were inoculated as described above and incubated for 7 days. Each fruit half was weighed and then macerated in $1 \mathrm{ml}$ of $1 \times$ PBS buffer. Bacterial population density was determined by standard serial dilution plating. Each experiment consisted of four biological replicates. One-way ANOVA and Tukey's HSD $(\alpha=0.05)$ were used to determine separation between the means of the bacterial populations. Experiments were performed three times with similar results. 
Biochemical characterization. Acid production from arginine, cellobiose, D-glucose, glycerol, L-arabinose, mannose, ribose, sorbitol, sucrose, and trehalose was tested based on Bergey's Manual of Systematic Bacteriology (40). Dye's C media supplemented with specific carbohydrate $(5 \mathrm{~g} / \mathrm{liter})$ were used for acid production assays $(29,34)$. Indole production and reducing sugars from sucrose assays were performed following established protocols (34).

Growth rate in liquid media. For liquid culture growth analyses, each E. amylovora strain was grown overnight on culture plates as described above. Cells were harvested by flooding plates with liquid M9 minimal media supplemented with nicotinic acid $\left(6 \mathrm{~g}\right.$ of $\mathrm{Na}_{2} \mathrm{HPO}_{4}, 3 \mathrm{~g}$ of $\mathrm{KH}_{2} \mathrm{PO}_{4}, 0.5 \mathrm{~g}$ of $\mathrm{NaCl}, 1.0 \mathrm{~g}$ of $\mathrm{NH}_{4} \mathrm{Cl}, 0.24 \mathrm{~g}$ of $\mathrm{MgSO}_{4}, 0.2 \mathrm{~g}$ of nicotinic acid, and $0.2 \mathrm{~g}$ of thiamine per liter) and were washed twice with M9 media. Cell suspensions were brought to an optical density at $600 \mathrm{~nm}\left(\mathrm{OD}_{600}\right)$ of 0.1 ; then, $3.5 \mathrm{ml}$ was inoculated into $33.5 \mathrm{ml}$ of M9 minimal media with nicotinic acid, supplemented with specific sugars to a final concentration of $1 \%$. Three tubes per media type were inoculated per strain to an initial $\mathrm{OD}_{600}$ of 0.01 . Cultures were grown at $28^{\circ} \mathrm{C}$ with agitation at $250 \mathrm{rpm}$ for the duration of the experiment. CFU ml ${ }^{-1}$ was determined at $0,12,24,36,48$, and $60 \mathrm{~h}$ by serial dilution plating. CFU ml ${ }^{-1}$ was transformed to the $\log$ scale. The rate of growth for each strain in the various sugars was obtained by linear regression of the $\log$ of the CFU ml $\mathrm{ml}^{-1}$ against time (42). Experiments were repeated three times.

Biofilms. For assessment of biofilm formation, E. amylovora strains were inoculated into 12-well culture plates containing LB broth and incubated without agitation for $48 \mathrm{~h}$ at $28^{\circ} \mathrm{C}$ to allow bacterial aggregation on the well walls (55). Plates were gently washed with $1 \times$ PBS three times. Each well was then filled with $2 \mathrm{ml}$ of $0.01 \%$ (wt/vol) crystal violet solution and incubated for $30 \mathrm{~min}$ at room temperature. Plates were rinsed again three times with $1 \times$ PBS to wash away unattached cells and unbound crystal violet. Crystal violet was solubilized with $2 \mathrm{ml}$ of $95 \%$ ethanol and absorbance at $590 \mathrm{~nm}$ was determined. Each experiment included four biological replicates per strain, and each experiment was repeated three times. Data were analyzed using one-way ANOVA, and Tukey's HSD was used to determine separation between means $(\alpha=0.05)$.

Determination of levansucrase activity. The determination of secreted levansucrase activity was carried out as previously described, with modification (9). Single colonies of each strain were inoculated in Standard I media (15.0 g of peptone, $3.0 \mathrm{~g}$ of yeast extract, $6.0 \mathrm{~g}$ of $\mathrm{NaCl}$, and $1.0 \mathrm{~g}$ of $\mathrm{D}(+)$ glucose per liter) and incubated at $28^{\circ} \mathrm{C}$ for $48 \mathrm{~h}$ at $250 \mathrm{rpm}$. Bacteria were removed from cultures by centrifugation and $1 \mathrm{ml}$ of cell-free supernatant was added to $1 \mathrm{ml}$ of LS buffer $\left(50 \mathrm{mM} \mathrm{Na}_{3} \mathrm{PO}_{4}, 2 \mathrm{M}\right.$ sucrose, and $0.05 \% \mathrm{NaN}_{3}$ ). After $24 \mathrm{~h}$ of incubation at $37^{\circ} \mathrm{C}$, absorbance was determined at $590 \mathrm{~nm}$. Each experiment included four biological replicates per strain, and the experiment was performed three times. Data were analyzed using one-way ANOVA, and Tukey's HSD was used to determine separation between means $(\alpha=0.05)$.

Production of amylovoran. Production of amylovoran was determined using the turbidity assay described by Bellemann et al. (6). Cells were grown at $28^{\circ} \mathrm{C}, 250 \mathrm{rpm}$ for $48 \mathrm{~h}$ in liquid minimal media (4.0 $\mathrm{g}$ of L-asparagine, $6 \mathrm{~g}$ of $\mathrm{Na}_{2} \mathrm{HPO}_{4}, 3 \mathrm{~g}$ of $\mathrm{KH}_{2} \mathrm{PO}_{4}, 0.5 \mathrm{~g}$ of $\mathrm{NaCl}, 1.0 \mathrm{~g}$ of $\mathrm{NH}_{4} \mathrm{Cl}, 0.24 \mathrm{~g}$ of $\mathrm{MgSO}_{4}, 0.2 \mathrm{~g}$ of nicotinic acid, and $0.2 \mathrm{~g}$ of thiamine per liter) supplemented with $1 \%$ sorbitol. Bacteria were removed from cultures by centrifugation and $1 \mathrm{ml}$ of cell-free supernatant was mixed with $50 \mu \mathrm{l}$ of cetylpyridinium chloride $\left(50 \mathrm{mg} \mathrm{ml}^{-1}\right)$ in water. Absorption was measured at $590 \mathrm{~nm}$ after $10 \mathrm{~min}$ of incubation. Each experiment included four biological replicates per strain and was repeated three times. Data were analyzed using one-way ANOVA, and Tukey's HSD was used to determine separation between means $(\alpha=0.05)$.
Multiple regression analysis. Multiple regression analysis was used to investigate the relative importance of various virulence factors in expression of disease severity. Values of the mean of disease severity levels on open pollinated 'Gala' apple seedlings and greenhouse-grown 'Gala' trees on Bud.9 rootstock inoculated with the various bacterial strains were regressed against values quantifying the levels of amylovoran, biofilm formation, levansucrase activity, growth rates in different sugars (glucose, fructose, sucrose, and sorbitol), hypersensitive cell death induction in tobacco, and bacterial population size in host tissue $\left(\mathrm{CFU} \mathrm{g} \mathrm{g}^{-1}\right.$ of immature apple fruit tissue). The multiple regression models were fitted with a stepwise selection method using PROC REG of the SAS software (SAS Institute Inc., Cary, NC). Values were included in the model only if their variance ratio was $\geq 2$ (1). The selected model was evaluated for goodness of fit based on plots of standardized residuals against fitted values as well as the coefficient of determination $\left(R^{2}\right)$. The relative contribution of individual explanatory variables (the virulence factors) was assessed based on the mean square error in the accumulated ANOVA and the corresponding $F$ test statistic (1).

Plasmid characterization. E. amylovora plasmids were isolated by alkaline lysis extraction followed by ethanol precipitation (58). Plasmids were resolved by electrophoresis through a $0.7 \%$ agarose gel and visualized using ethidium bromide. Plasmid size was determined by comparison to a $\lambda$-HindIII ladder (New England Biolabs, Ipswich, MA).

Protein secretion analysis. The six E. amylovora strains were grown in $20 \mathrm{ml}$ of $\mathrm{LB}$ for $18 \mathrm{~h}$ at $27^{\circ} \mathrm{C}$. Pelleted cells were washed twice with hrp-inducing medium containing mannitol (HMM) (31), brought to an $\mathrm{OD}_{600}$ of 0.2 in $100 \mathrm{ml}$ of HMM, grown at $18^{\circ} \mathrm{C}$ with shaking, and collected at $26 \mathrm{~h}$, during the exponential growth phase. The bacterial cultures were quickly adjusted to an $\mathrm{OD}_{600}$ of 0.37 with $\mathrm{HMM}$, and a 1-ml aliquot was set aside and used to determine $\mathrm{CFU} \mathrm{m} \mathrm{m}^{-1}$ for each culture by serial dilution plating. The remainder of the culture was chilled for immediate protein collection.

Secreted proteins in the culture supernatants were collected as previously described $(30,61)$. Briefly, culture supernatants were clarified by two centrifugation steps to remove bacterial cells. Proteins in $46 \mathrm{ml}$ of the resulting cell-free culture supernatant were concentrated by overnight trichloroacetic acid (TCA) precipitation. The TCA pellets were washed with acetone and resuspended in $110 \mu$ of $1 \times$ electrophoresis loading buffer (38). Then, $3 \mu \mathrm{l}$ of $1 \mathrm{M}$ Tris- $\mathrm{HCl}$ ( $\mathrm{pH} 8$ ) was added to each sample, and samples were stored at $-20^{\circ} \mathrm{C}$.

Supernatant proteins were resolved by sodium dodecyl sulfate polyacrylamide gel electrophoresis (SDS-PAGE). The amount of protein loaded in each lane represented a culture supernatant volume containing $2 \times 10^{9} \mathrm{CFU}$ for HrpN gels and $6 \times 10^{9} \mathrm{CFU}$ for DspA/E gels. Duplicate gels were produced, one for transfer to nitrocellulose membrane and the other for silver staining. HrpN Western blotting was done using $12 \%$ gels; DspA/E Westerns were performed using $7.5 \%$ gels. Each gel included Precision Plus protein markers (Bio-Rad Corp., Hercules, CA). The membranes were probed with anti-HrpN or anti-DspA/E polyclonal antibodies (gifts of S. V. Beer, Cornell University) at 1:10,000 or 1:200 dilution, respectively. Secondary antibody (horseradish peroxidase-conjugated donkey anti-rabbit) (GE Healthcare, Piscataway, NJ) was used at 1:10,000 and protein bands were detected with the ECL Plus kit (GE Healthcare), using Pierce CLXPosure film (Thermo Scientific, Rockford, IL). The experiment was conducted twice in its entirety.

\section{RESULTS}

Comparison of disease severity caused by six $E$. amylovora isolates. E. amylovora strain HKN06P1 is a new strain (Table 1) that was isolated during the course of routine diagnostic process- 


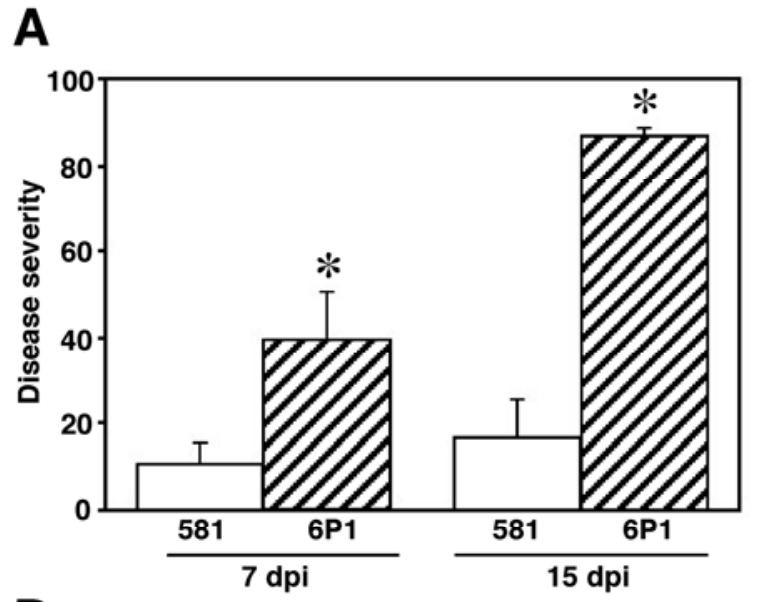

B

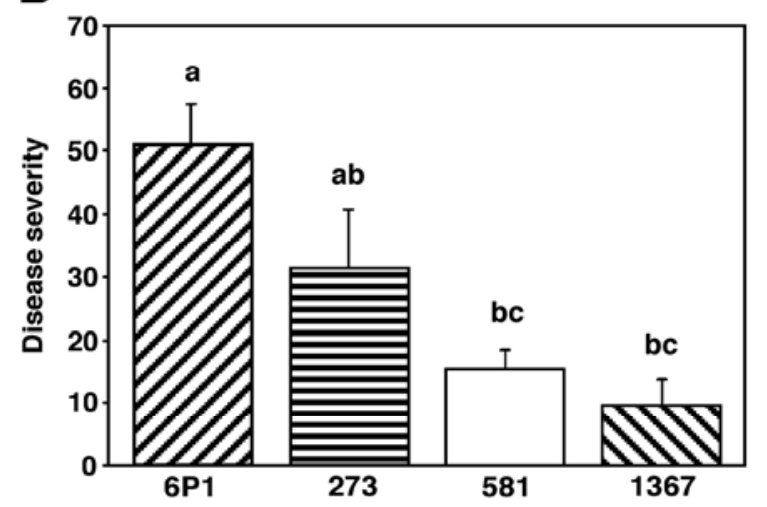

C

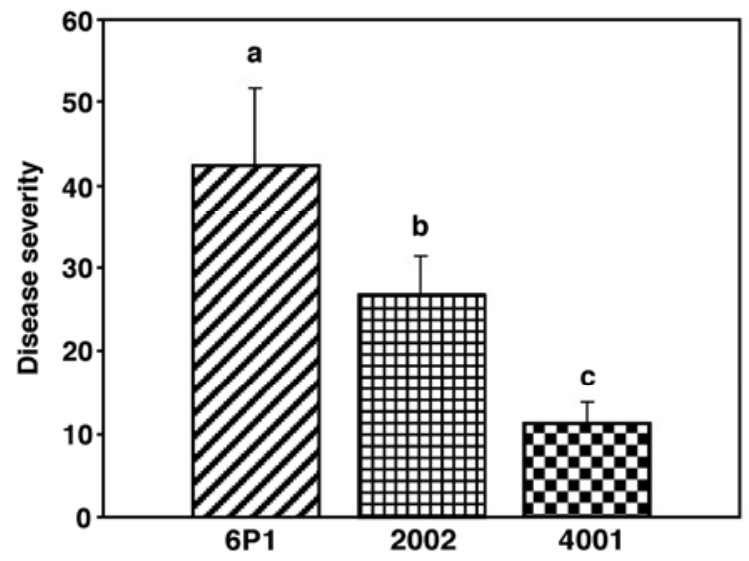

Fig. 1. Comparisons of Erwinia amylovora strains in terms of disease severity. Disease severity is expressed as the proportion of shoot length that was necrotic. A, Disease severity in 3-year-old, field-grown apple trees inoculated with E. amylovora strain HKN06P1 or Ea581a at 7 and 15 days postinoculation (dpi). Bars represent the means of three experiments containing 20 replicates each. Error bars represent standard deviations. Asterisk denotes significance of $P<0.005$ between HKN06P1 and Ea581a at each time point as determined by Student's $t$ test. B, Disease severity in open-pollinated apple seedlings inoculated with E. amylovora strain HKN06P1, Ea273, Ea581a, or CFBP1367 at $15 \mathrm{dpi}$. Bars represent the means of four replicates. Error bars represent standard deviations. Means with the same letters are not significantly different as determined by one-way analysis of variance (ANOVA) with Tukey's test $(P \leq 0.05)$. The experiment was performed thrice with similar results; panel depicts results from a representative experiment. C, Disease severity in ungrafted 'Gala' trees inoculated with E. amylovora strain HKN06P1, E2002a, or E4001a at 15 dpi. Bars represent the means of three replicates. Error bars represent standard deviations. Means with the same letters are not significantly different as determined by one-way ANOVA with Tukey's test $(P \leq 0.05)$. The experiment was performed twice with similar results; panel depicts results from a representative experiment. ing of samples submitted to The Pennsylvania State University Fruit Research and Extension Center in Biglerville. HKN06P1 caused significantly greater disease severity than the benchmark E. amylovora isolate Ea581a at both 7 and 15 dpi on 3-year-old, orchard-grown trees (Fig. 1A). At 7 dpi, shoots inoculated with HKN06P1 had a mean disease severity of $40 \pm 11 \%$ (standard deviation), while shoots inoculated with Ea581a had a mean disease severity of $11 \pm 5 \%$. At $15 \mathrm{dpi}$, shoots inoculated with HKN06P1 had a mean disease severity of $85 \pm 2 \%$ compared with $17 \pm 11 \%$ for shoots inoculated with Ea581a (Fig. 1A).

Because HKN06P1 caused greater disease severity than Ea581a, we decided to compare HKN06P1 to three well-studied E. amylovora strains in terms of disease severity caused on apple seedlings. Six-month-old seedlings from open-pollinated 'Gala' parents were inoculated with E. amylovora strains HKN06P1, Ea273, Ea581a, and CFBP1367, and disease severity was assessed at 15 dpi (Fig. 1B). Ea273 and CFBP1367 were chosen for comparison because they are well-characterized, standard strains used in fire blight research $(13,18,46,47,51,62)$; Ea581a was isolated from the same geographic region as HKN06P1 and has been used extensively by our research group. Seedlings inoculated with HKN06P1 had a mean disease severity of $51 \pm$ $6 \%$ at $15 \mathrm{dpi}$, whereas seedlings inoculated with Ea273 had a disease severity of $32 \pm 10 \%$ (Fig. 1B). Seedlings inoculated with Ea581a and CFBP1367 had disease severities of $16 \pm 3$ and $10 \pm$ $4 \%$, respectively. ANOVAs indicated that the disease severity caused by Ea581a and CFBP1367 were significantly less than that caused by HKN06P1 $(P<0.001)$. Of the four strains, HKN06P1 caused the greatest disease severity in seedlings.

Because HKN06P1 appeared to be a highly virulent strain, it was compared with E. amylovora strains E2002a and E4001a, which are known to be highly virulent (48-51). HKN06P1 produced greater disease severity than either E2002a or E4001a on ungrafted Gala trees growing in a growth chamber (Fig. 1C). Trees inoculated with HKN06P1 had a mean disease severity of $42 \pm 9 \%$ at $15 \mathrm{dpi}$, whereas trees inoculated with E2002a and E4001a had disease severities of $26 \pm 4$ and $11 \pm 2 \%$, respectively. ANOVAs indicated that the disease severity caused by E2002a and E4001a was significantly less than that caused by HKN06P1 $(P<0.001)$.

Disease severity was also assessed in greenhouse-grown Gala trees inoculated with E. amylovora strains HKN06P1, Ea273,

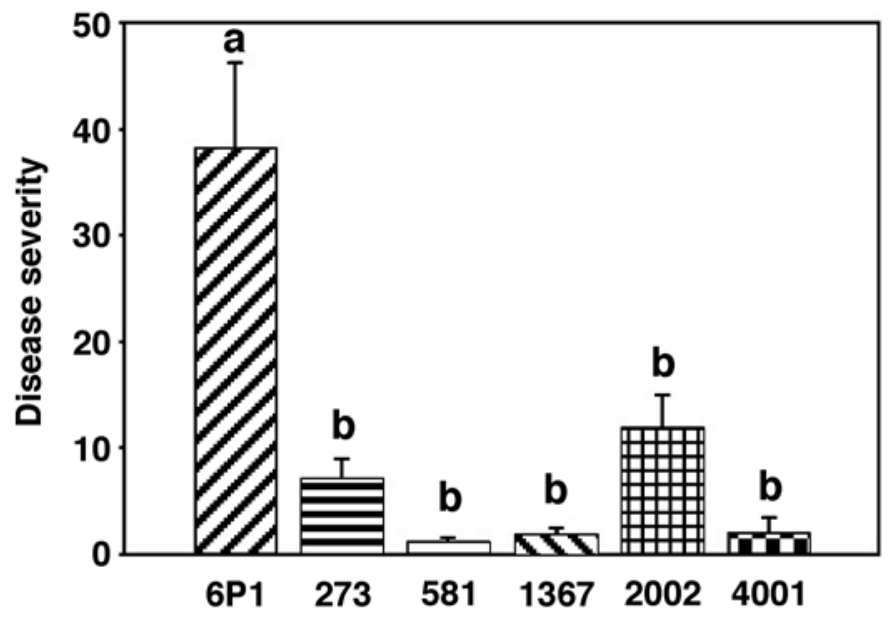

Fig. 2. Comparison of disease severity caused by Erwinia amylovora strains HKN06P1, Ea273, Ea581a, CFBP1367, E2002a, and E4001a in greenhousegrown 'Gala' apple trees with Bud.9 rootstocks at 15 days postinoculation. Trees were inoculated by shoot tip wound inoculation. Disease severity is expressed as the proportion of shoot length that was necrotic. Bars represent the means of four replicates. Error bars represent standard error. Means with the same letters are not significantly different as determined by one-way analysis of variance with Tukey's test $(P \leq 0.05)$. 
Ea581a, CFBP1367, E2002a, and E4001a. Disease severity was assessed at 15 dpi (Fig. 2). Trees inoculated with HKN06P1 had a mean disease severity of $38 \pm 8 \%$. Trees inoculated with E2002a and Ea273 had disease severities of $12 \pm 3$ and $7 \pm 1.7 \%$, respectively. Trees inoculated with Ea581a, CFBP1367, and E4001a had disease severities of $1.3 \pm 0.4,1.9 \pm 0.7$, and $2 \pm 1.4 \%$, respectively. ANOVAs indicated that the disease severity caused by HKN06P1 was significantly more than the rest of the strains $(P<0.0001)$.

Comparative ability to grow in and colonize host tissue. Immature apple fruit from open-pollinated cv. Gala trees were inoculated with E. amylovora isolates HKN06P1, Ea273, Ea581a, CFBP1367, E2002a, and E4001a. Bacterial populations in inoculated fruit were assessed at 7 dpi by tissue maceration and serial dilution plating. HKN06P1 and E2002a exhibited signifi-

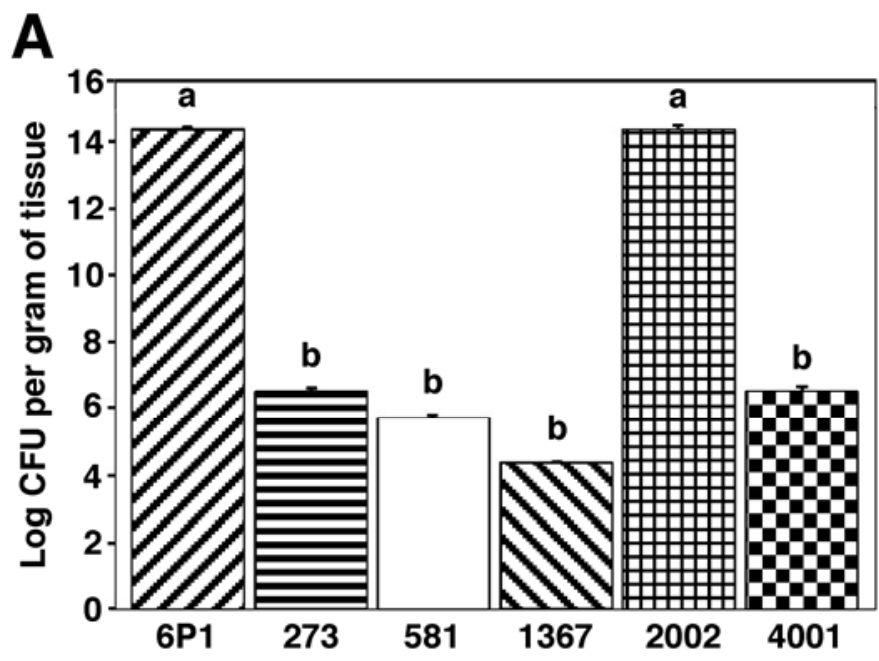

B

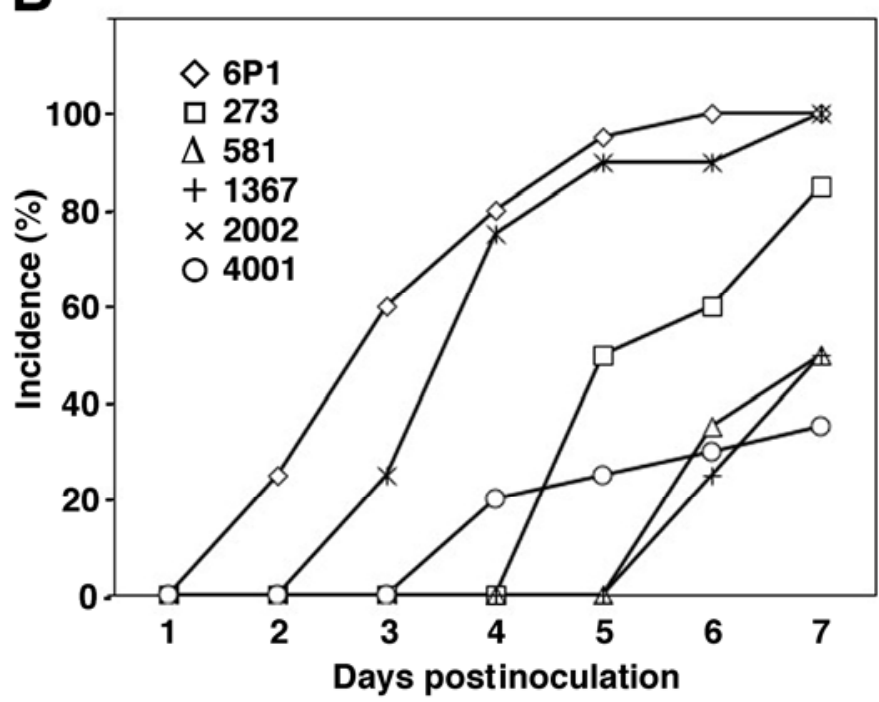

Fig. 3. Comparison of Erwinia amylovora strains HKN06P1, Ea273, Ea581a, CFBP1367, E2002a, and E4001a in terms of bacterial population and disease incidence in immature 'Gala' apple fruit. A, Populations of E. amylovora strains in immature apple fruit at 7 days postinoculation with $1 \times 10^{8} \mathrm{CFU}$ of the indicated E. amylovora strains. Bars represent means of four replicates; means with the same letters are not significantly different as determined by one-way analysis of variance with Tukey's test $(P \leq 0.05)$. The experiment was performed thrice with similar results; panel depicts results from a typical experiment. B, Disease incidence over time in immature apple fruit inoculated with the indicated E. amylovora strains. Twenty-five immature fruit were used for each strain; incidence was scored when bacterial ooze was first observed emerging from fruit lenticels. The experiment was performed thrice with similar results; panel depicts results from one experiment. cantly higher $(P<0.0001)$ population levels than the other four strains (Fig. 3A). In addition, HKN06P1 and E2002a caused higher rates of disease incidence than the four other strains (Fig. 3B). Incidence was measured at the first emergence of ooze from the fruit lenticels. Disease incidence in fruit inoculated with strains HKN06P1 and E2002a appeared as early 2 and 3 dpi, respectively, whereas symptoms appeared at 4 to 9 dpi in fruit inoculated with the four other strains (Fig. 3B). Furthermore, disease incidence reached $100 \%$ in fruit inoculated with HKN06P1 or E2002a at $7 \mathrm{dpi}$, whereas none of the other four strains reached $100 \%$ incidence by 7 dpi.

Comparative biofilm and extracellular polysaccharide production. The relative ability of the six strains to form biofilms in static cultures was assessed using crystal violet staining (Fig. 4). HKN06P1 and E2002a produced the most biofilm, followed by E4001a, CFBP1367, Ea581a, and Ea273. Amylovoran and levan are two major polysaccharides produced by E. amylovora, and they contribute to E. amylovora pathogenicity and are a major component of biofilm aggregates $(28,55)$. E. amylovora strains HKN06P1, Ea273, and E4001a produced significantly more amylovoran than Ea581a, CFBP1367, and E2002a $(P<0.0001)$ (Fig. $5 \mathrm{~A})$. However, no statistically significant differences in levansucrase activity were observed among the six strains (Fig. 5B).

Comparative growth rates in minimal media supplemented with different sugars. Carbohydrate utilization is important in bacterial growth and plays a role in pathogenicity (2). Because sorbitol, sucrose, glucose, and fructose are the major carbohydrates in Malus $\times$ domestica $(16,19,66)$, we tested the ability of the six E. amylovora isolates to utilize these four sugars. Each strain was grown in liquid M9 minimal media (described in the Materials and Methods) supplemented with $1 \%$ of the appropriate sugar, and bacterial population growth over time was measured by serial dilution plating. By transforming $\mathrm{CFU} \mathrm{ml^{-1 }}$ measurements to the $\log$ scale and analyzing them by linear regression, we obtained growth rates for each strain in each of the four different media (Fig. 6). HKN06P1 and CFBP1367 grew fastest in M9 media supplemented with sorbitol, followed by E2002a, Ea273, Ea581a, and E4001a, with significant separations among the strains $(P<0.001)$. The mean growth rate of each strain was very similar no matter what the carbon source.

Comparative metabolic profiles. Because differences in sugar utilization in culture were observed among the six E. amylovora strains, metabolic profiling was performed (Table 2). We performed a set of biochemical analyses to compare carbon utilization profiles of E. amylovora strains HKN06P1, Ea273, Ea581a,

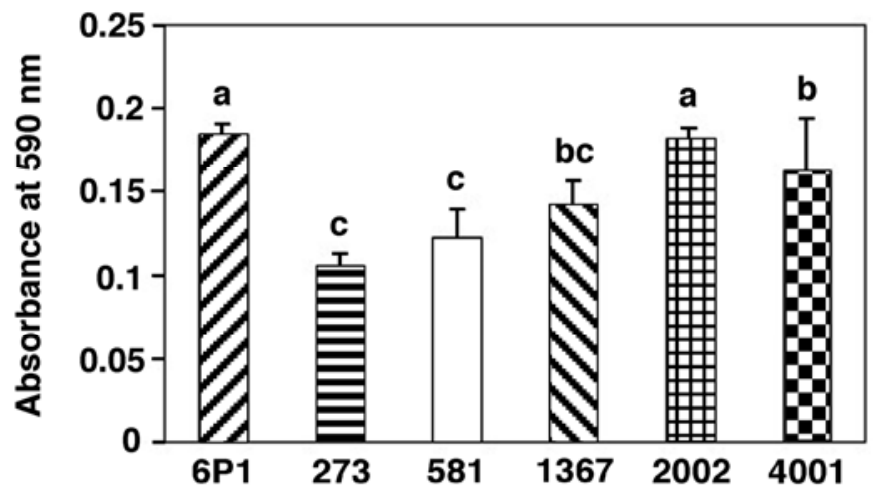

Fig. 4. Comparison of Erwinia amylovora strains HKN06P1, Ea273, Ea581a, CFBP1367, E2002a, and E4001a in terms of biofilm formation. Biofilm formation by E. amylovora strains grown in static cultures for $48 \mathrm{~h}$ was determined using crystal violet staining. Bars represent means of four replicates. Error bars represent standard deviations. Means with the same letter are not significantly different as determined by one-way analysis of variance with Tukey's test $(P \leq 0.05)$. The experiment was performed thrice with similar results each time; figure depicts results from a representative experiment. 
and CFBP1367, E2002a, and E4001a, as well as a lab isolate of Dickeya dadantii (formerly E. chrysanthemi) (Table 1). HKN06P1 and E4001a differed from the other E. amylovora strains in that they produced large amounts of reducing sugars from sucrose. HKN06P1 was the only E. amylovora strain that displayed weak acid production from sorbitol. Neither HKN06P1 nor E4001a had detectable acid production from mannose. All the E. amylovora strains analyzed produced acid from D-glucose, Larabinose, sucrose, and trehalose. None of the E. amylovora strains tested produced acid from indole. Ea273 did not produce acid from cellobiose; Ea581a did not produce acid from glycerol. Surprisingly, four of the six E. amylovora strains had acid production from cellobiose, a trait relatively rare in E. amylovora (40).

Plasmid profiles. Native plasmid profiles were obtained for all six E. amylovora strains (Fig. 7). All six strains contained pEA29, as expected. Ea273 and CFBP1367 contained pCPP60, as previously reported (62) whereas HKN06P1, Ea581a, E2002a, and E4001a did not contain pCPP60.

Comparative avirulence in tobacco. Virulence of E. amylovora is associated with the ability to cause a hypersensitive reaction (HR) on nonhost tobacco plants $(4,35,63)$. Therefore, the relative effectiveness of the six E. amylovora strains used in this study at triggering the HR was assessed. Leaves of 6-week-old $N$. tabacum L. cv. Glurk plants were infiltrated with suspensions of E. amylovora strains HKN06P1, Ea273, Ea581a, CFBP1367, E2002a, and E4001a at a series of bacterial concentrations rang-

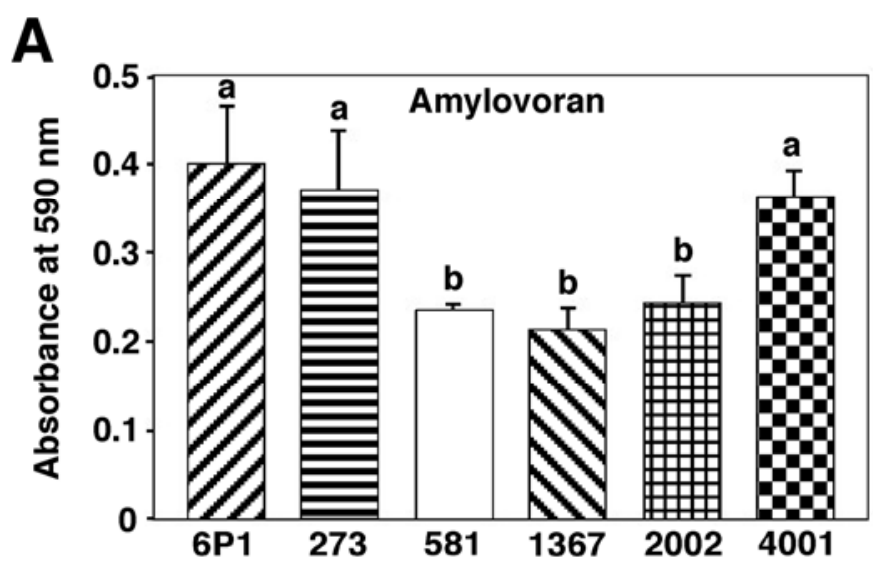

B

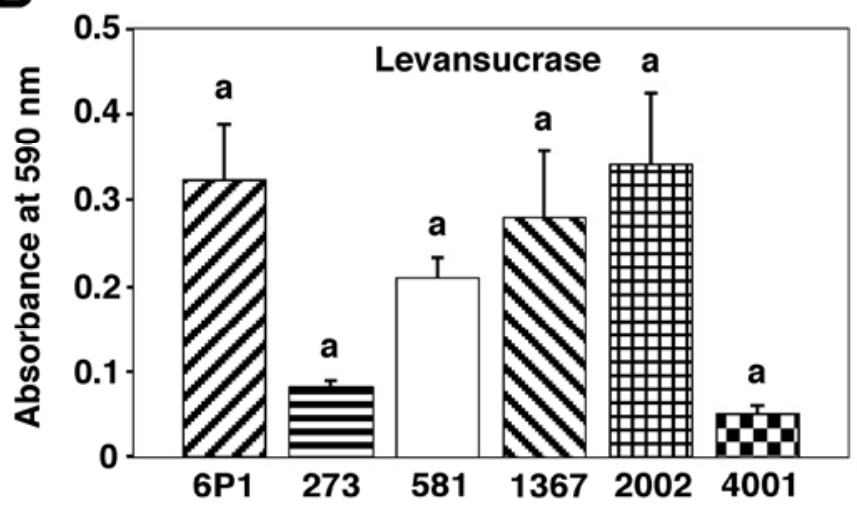

Fig. 5. Comparison of Erwinia amylovora strains HKN06P1, Ea273, Ea581a, CFBP1367, E2002a, and E4001a in terms of amylovoran production and levansucrase activity. Bars represent means of at least three replicates. Error bars represent standard deviations; means with the same letters are not significantly different as determined by one-way analysis of variance with Tukey's test $(P \leq 0.05)$. Both experiments were performed thrice with similar results each time; each panel depicts results from a representative experiment. For experimental details, see the Materials and Methods. A, Amylovoran in culture supernatants as determined by the cetylpyridinium chloride assay. B, Levansucrase activity in culture supernatants.
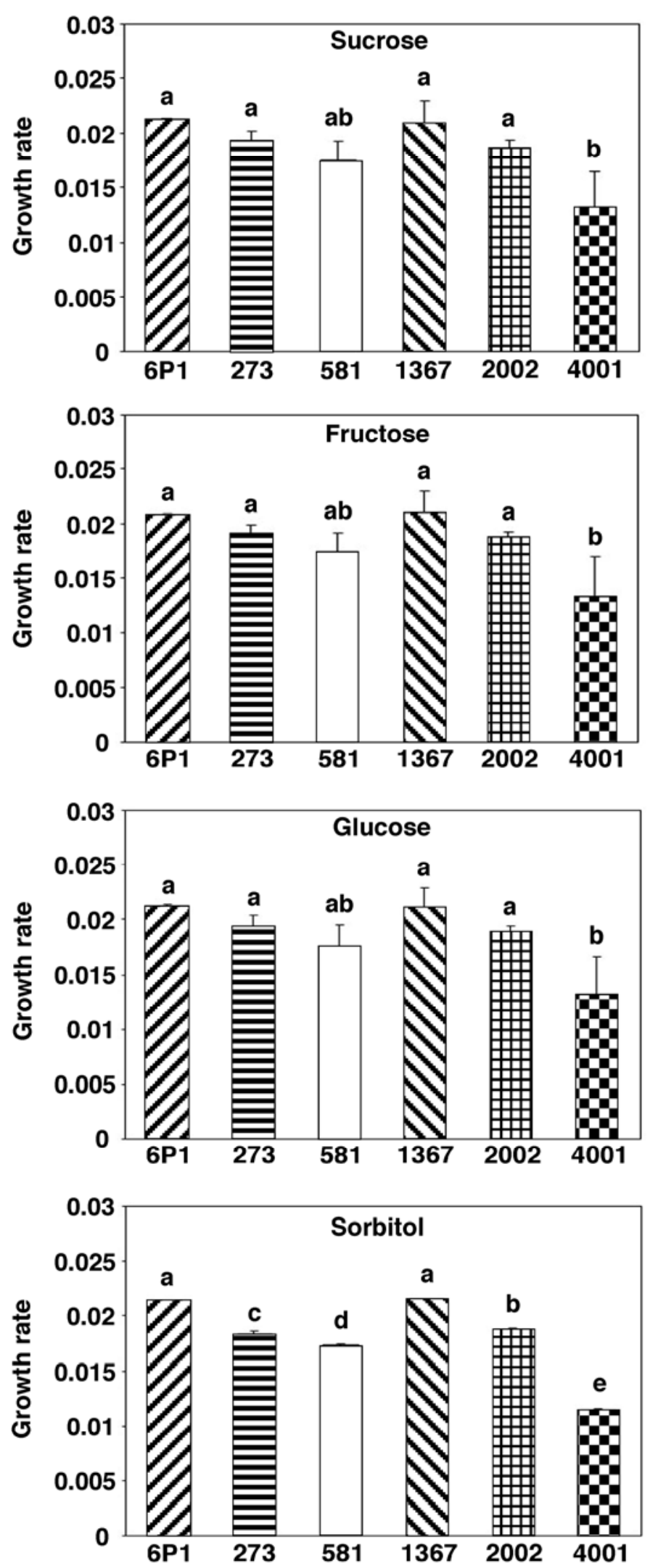

Fig. 6. Comparison of growth rates of Erwinia amylovora strains HKN06P1, Ea273, Ea581a, CFBP1367, E2002a, and E4001a in liquid M9 minimal media supplemented with sucrose, fructose, glucose, or sorbitol. Growth rate is log of CFU ml $\mathrm{m}^{-1}$ linearly regressed over $60 \mathrm{~h}$ of growth. Bars represent means of three independent experiments. Error bars represent standard error of means. Means with the same letter are not significantly different as determined by one-way analysis of variance with Tukey's test $(P \leq 0.05)$. 
ing from $1 \times 10^{5}$ to $1 \times 10^{8} \mathrm{CFU} \mathrm{ml}{ }^{-1}$, and the infiltrated areas were observed for hypersensitive tissue collapse at $24 \mathrm{~h}$ after infiltration (Fig. 8A). At $1 \times 10^{8} \mathrm{CFU} / \mathrm{ml}$, all six strains caused an HR; at $1 \times 10^{7} \mathrm{CFU} \mathrm{ml} \mathrm{m}^{-1}$, CFBP1367 caused a patchy HR while the five other strains caused complete HR collapse; at $1 \times 10^{6} \mathrm{CFU}$ $\mathrm{ml}^{-1}$, strain HKN06P1 caused a partial HR while no other strain caused any visible HR collapse; and at $1 \times 10^{5} \mathrm{CFU} \mathrm{ml}^{-1}$, none of the strains caused an HR.

To obtain a quantitative assessment of the ability of the six $E$. amylovora strains to cause an HR in tobacco, relative ion leakage was determined at $18 \mathrm{~h}$ postinfiltration with a bacterial suspension of $1 \times 10^{7} \mathrm{CFU} \mathrm{m}{ }^{-1}$ for each strain (Fig. 8B). Relative ion leakage measures the degree of tissue breakdown and cell death. HKN06P1 produced the largest amount of relative ion leakage. HKN06P1, Ea273, E2002a, and E4001a caused significantly more relative ion leakage than Ea581a and CFBP1367 $(P<0.0001)$.

Analysis of protein secretion. Because of the essential role of secreted proteins in the fire blight disease process, we compared protein secretion patterns among the six E. amylovora strains growing in hrp-inducing minimal media (Fig. 9). Protein loading was normalized according to bacterial cell number (see Materials and Methods). Considerable variations in supernatant protein profiles, including protein amounts and banding patterns, were revealed by SDS-PAGE followed by silver staining (Fig. 9A). Overall, HKN06P1 had a greater number of intensely stained supernatant protein bands than the other strains. Ea273 and E4001a appeared to have the fewest intensely staining bands compared with the other strains. Interestingly, Western blot analysis showed that HKN06P1 secreted more DspA/E than all the other strains (Fig. 9B). Strains E2002a and E4001a secreted large amounts of DspA/E compared with Ea273, Ea581a, and CFBP1367, which had relatively little DspA/E secretion. In contrast to the wide variation in DspA/E secretion, there was little variation in the secretion of $\mathrm{HrpN}$ among the strains, although Ea273 and Ea581a had somewhat less HrpN secretion than the other four strains (Fig. 9C).

Multiple regression analysis of disease in seedlings. The regression equation relating virulence characteristic expression level to disease severity in seedling plants was highly significant $(F=19.01 ; P<0.0001)$ and accounted for $70.1 \%$ of the variance in the response variable (disease severity). Plots of the standardized residuals against fitted values along with normalized probability plots of the residuals indicated the model was a good fit for the data and that the criteria for multiple regression analyses were certified. Of all the virulence characteristics evaluated, only growth in host tissue, biofilm formation, and amylovoran production were significantly $(0.001 \leq P \leq 0.018)$ related to levels of disease severity. Amylovoran production and growth in host tissue accounted for most of the variation in the response variable, having variance ratios of 28.35 and 22.07, respectively (Table 3).
Multiple regression analysis of disease in greenhouse-grown 'Gala' trees. Multiple regression analysis revealed a highly significant $(F=45.59 ; P<0.0001)$ relationship between disease severity in greenhouse-grown 'Gala' trees and several of the virulence characteristics (Table 4), with the regression model accounting for $75.8 \%$ of the variation in disease severity. As with the model for disease severity on seedling plants, bacterial growth rate in immature fruit accounted for most of the variation in disease severity in greenhouse-grown trees. Amylovoran levels and biofilm formation, which were also important in explaining the level of disease in seedlings, also accounted for significant variation in disease severity in the greenhouse trees (Table 4).

In addition, electrolyte leakage and bacterial growth rates in sorbitol were significantly related to disease severity in greenhouse-grown trees, accounting for more variation than biofilm formation and amylovoran production (Table 4). Growth rate in sorbitol was the second most important virulence factor related to disease severity in greenhouse-grown trees, accounting for nearly $25 \%$ of the variation in disease severity levels. Also, correlation analysis showed that electrolyte leakage was strongly correlated with growth in immature fruit $(r=0.612 ; P<0.0001)$. Based on these results, bacterial growth rate in immature apple fruit, electrolyte leakage, growth in sorbitol, amylovoran production, and biofilm formation were the best indicators of strain virulence status in greenhouse-grown apple trees.

\section{DISCUSSION}

The purpose of this study was to document differences in disease severity caused by six different E. amylovora strains, profile the six strains for traits associated with virulence, and determine whether variation in traits associated with virulence accounted for differences in disease severity caused by the strains. The results of the study are summarized in Table 5. Differences in bacterial growth in host tissue (immature apple fruit), amount of

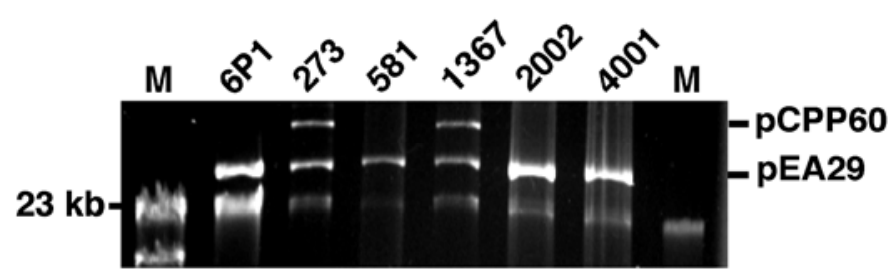

Fig. 7. Comparison of plasmid profiles of Erwinia amylovora strains HKN06P1, Ea273, Ea581a, CFBP1367, E2002a, and E4001a. Plasmid profiles were determined by alkaline lysis plasmid isolation, electrophoresis through a $0.8 \%$ agarose gel, and ethidium bromide staining. Migration points of pEA29 and pCPP60 are indicated. M, lane containing $\lambda$ HindIII marker; migration point of $23-\mathrm{kb}$ marker band is labeled.

TABLE 2. Biochemical characterization of six strains of Erwinia amylovora ${ }^{\text {a }}$

\begin{tabular}{|c|c|c|c|c|c|c|c|}
\hline Test & $6 \mathrm{P} 1$ & 273 & 581 & 1367 & 2002 & 4001 & D. dadantii \\
\hline Mannose & - & + & + & \pm & \pm & - & + \\
\hline Glycerol & + & + & - & \pm & + & + & + \\
\hline D-Glucose & + & + & + & + & + & + & + \\
\hline Cellobiose & + & - & + & + & + & - & + \\
\hline Arginine & + & + & + & + & - & - & + \\
\hline L-Arabinose & + & + & + & + & + & + & + \\
\hline Ribose & + & + & + & + & + & \pm & + \\
\hline Sorbitol & \pm & + & + & + & + & + & - \\
\hline Sucrose & + & + & + & + & + & + & + \\
\hline Trehalose & + & + & + & + & + & + & - \\
\hline Indole $^{b}$ & - & - & - & - & - & - & + \\
\hline Reducing substances from sucrose & ++ & + & + & + & + & +++ & - \\
\hline
\end{tabular}

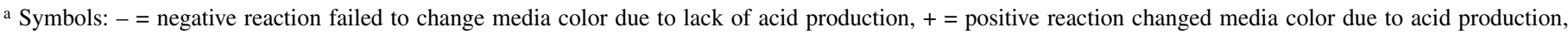
$\pm=$ weak reaction as determined by changed media color due to acid production, and $+++=$ greater color change when compared with other positives.

b Negative reaction is a colorless or light pink reaction and positive is a blue-green color change. 
amylovoran production in culture, and amount of biofilm formation in culture accounted for $>70 \%$ of the variation in disease severity caused by HKN06P1, Ea237, Ea581a, and CFBP1367 in open-pollinated 'Gala' apple seedlings. Furthermore, differences in bacterial growth in host tissue (immature apple fruit), growth rate in sorbitol, amount of amylovoran production in culture, amount of biofilm formation in culture, and electrolyte leakage due to hypersensitive cell death accounted for $75.8 \%$ of the variation in disease severity caused by all six strains in greenhouse-grown 'Gala' apple trees. This indicates that variation in traits associated with virulence plays a major role in determining E. amylovora virulence levels in natural populations. However, this study is limited in that only one type of host (apple) and, mainly, one cultivar ('Gala') was used.

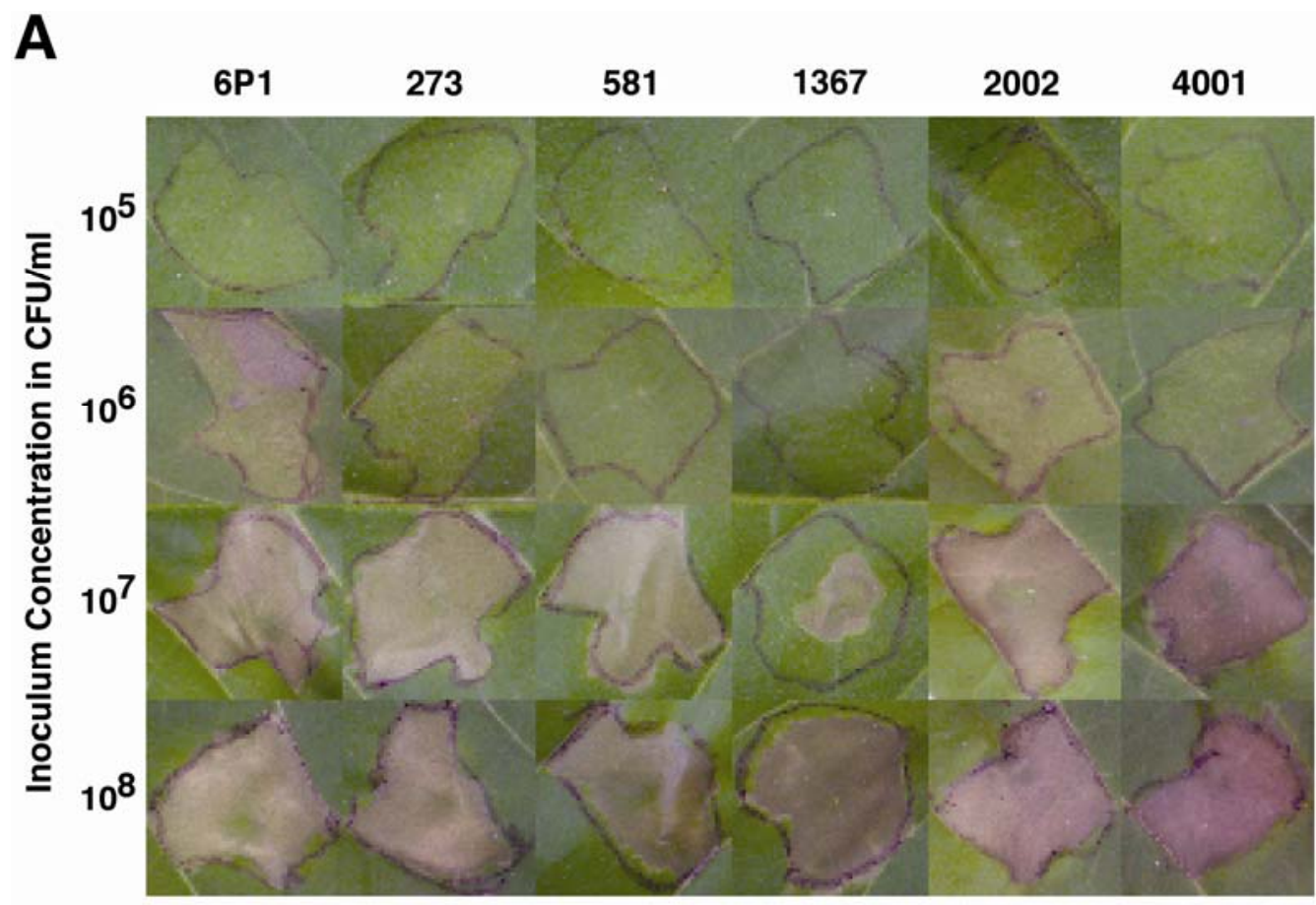

B

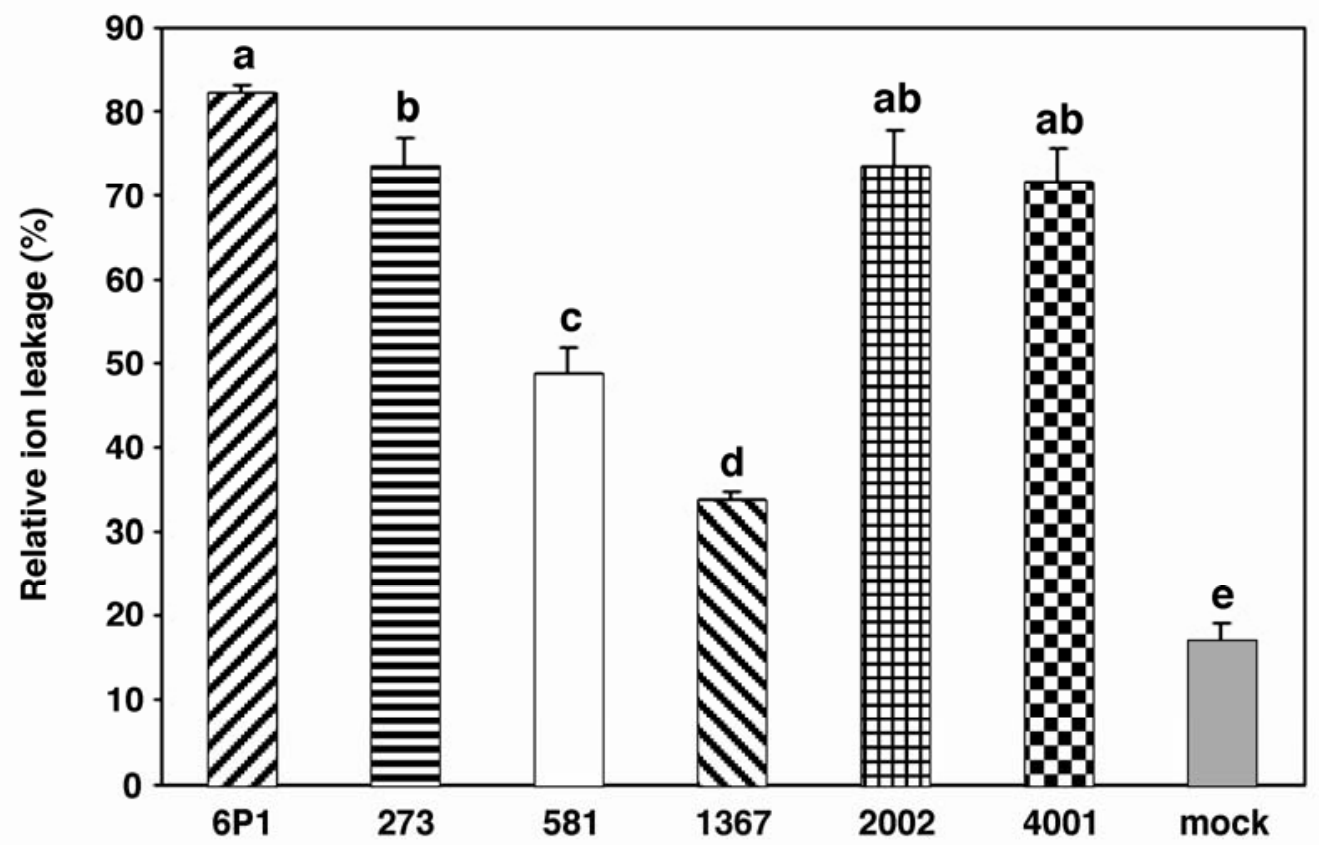

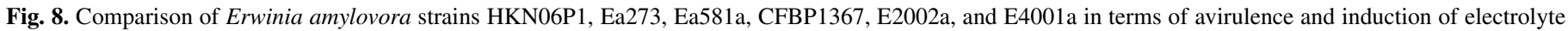

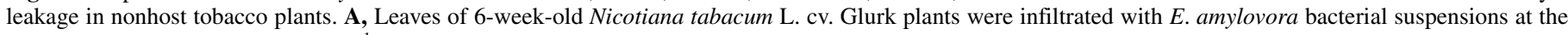

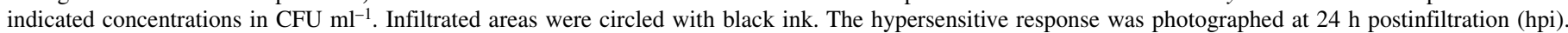

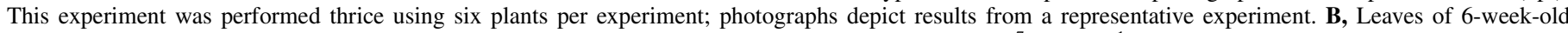

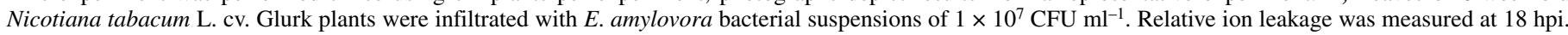

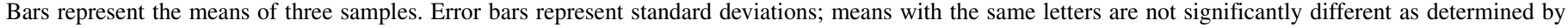

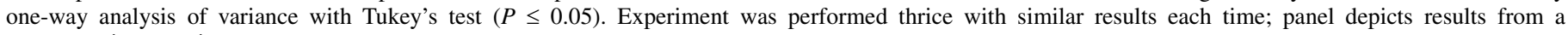
representative experiment. 
Our results support the use of immature apple fruit tissue as a model system for the study of E. amylovora virulence. E. amylovora population size in immature fruit accounted for a substantial part of the variation in disease severity in apple seedlings. Furthermore, growth in immature fruit was the single most important virulence characteristic accounting for disease severity in apple trees. This means that growth in immature apple fruit is a robust indicator of E. amylovora virulence in apple trees.

Exopolysaccharide production is essential for E. amylovora virulence, because $E$. amylovora mutants blocked in amylovoran biosynthesis are not virulent (7). Our results build upon these findings by indicating that the level of amylovoran production contributes quantitatively to E. amylovora virulence. Interestingly, amylovoran production and biofilm formation are linked in $E$. amylovora (36), and we found both traits to account, in part, for disease severity in both apple seedlings and 'Gala' apple trees.

Although differences in growth rates in M9 minimal media supplemented with various sugars did not account for variations in disease severity in apple seedlings, growth in sorbitol accounted for nearly $25 \%$ of variation in disease severity in greenhouse-grown Gala apple trees (Table 4). Sorbitol is the most abundant form of transported carbon in apple $(19,66)$. Strikingly, CFBP1367 utilized sorbitol as effectively as HKN06P1 (Fig. 6), despite being much less virulent than HKN06P1 (Figs. 1B and 2). However, CFBP1367 was isolated from Crataegus sp. (Table 1), whereas all of the virulence assays performed for this study used apple hosts, which likely affected our assessment of CFBP1367 virulence. In any case, this result implies that disease severity is the result of a complex interaction of virulence characteristic expression and host adaptation. It is also notable that E4001a grew at the slowest rate in all four sugars tested (Fig. 6), which could account for its lower virulence compared with most of the other strains (Figs. 1C and 2).

All of the strains contained the plasmid pEA29, as expected. pEA29 is required for E. amylovora virulence $(25,39,43)$, and nearly all tested E. amylovora strains contain pEA29 (41). The larger plasmid pCPP60 was present only in Ea273 and CFBP1367. Plasmid pCPP60 does not appear to play a role in $E$. amylovora virulence (62). The presence of pCPP60 was not associated with particularly high or low disease severity in this study.

Differences were observed among the six E. amylovora strains in terms of the HR triggered on nonhost tobacco plants (Fig. 8). Interestingly, one of the least virulent strains (CFBP1367) was the least effective at producing the HR, whereas the most virulent strain (HKN06P1) was more effective at producing the HR (Fig. $8 \mathrm{~A})$. It is interesting to note that differences in electrolyte leakage accounted for a substantial amount of variation in disease severity caused by the six strains in 'Gala' apple trees, being even more important than biofilm formation and amylovoran production (Table 4). In addition, electrolyte leakage was strongly correlated with growth in immature apple fruit, which is a strong indicator of virulence. The E. amylovora $\mathrm{HR}$ on tobacco is primarily triggered by bacterial proteins secreted via the T3SS, such as HrpN, DspA/E, and HrpW $(14,26,27,67)$. The T3SS is also an essential pathogenicity factor for E. amylovora $(4,5,35,63)$. The correlation between electrolyte leakage in tobacco and disease severity in trees suggests that the more virulent strains may have more active type III secretion.

Interestingly, the highly virulent strain HKN06P1 characterized in this study and the two highly virulent strains noted in the literature (E2002a and E4001a) (48,49,51,57) secreted large amounts of $\mathrm{DspA} / \mathrm{E}$ protein in culture compared with the other three strains (Fig. 9). In contrast, HrpN secretion was relatively consistent among the strains. This suggests that DspA/E may be a rate-limiting contributor to fire blight disease severity in apple, whereas the amount of HrpN secretion may not be a rate-limiting factor.
Mutations in $d s p A / E$ result in an inability to produce disease symptoms such as ooze on immature fruit and necrosis in apple or pear seedlings $(14,27)$. DspA/E appears to have an important role in the induction of several important cellular functions, including cell death, plant defense reactions, and reactive oxygen species accumulation in host and nonhost plants $(20,21,53)$. Furthermore, Debroy et al. (20) suggest that suppression of basal immunity and promotion of necrosis by the AvrE family of effector proteins, including DspA/E, may play a role in aggressive colonization of plants. Therefore, increased secretion of DspA/E could very well contribute to disease severity, particularly in HKN06P1.

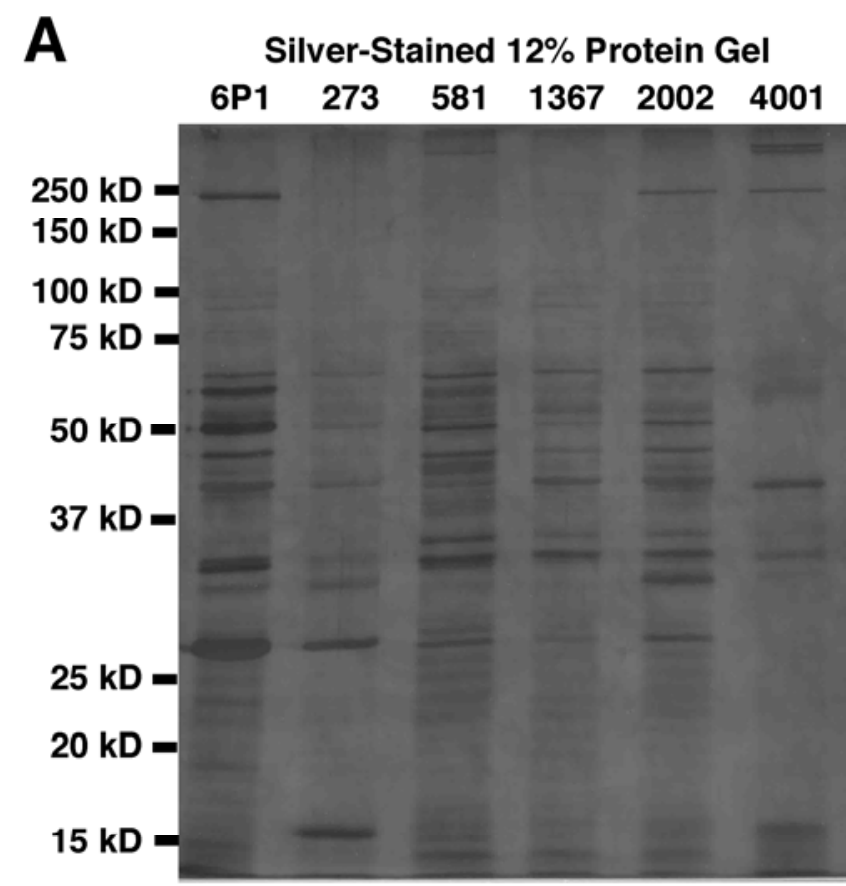

B

DspA/E Western Blot
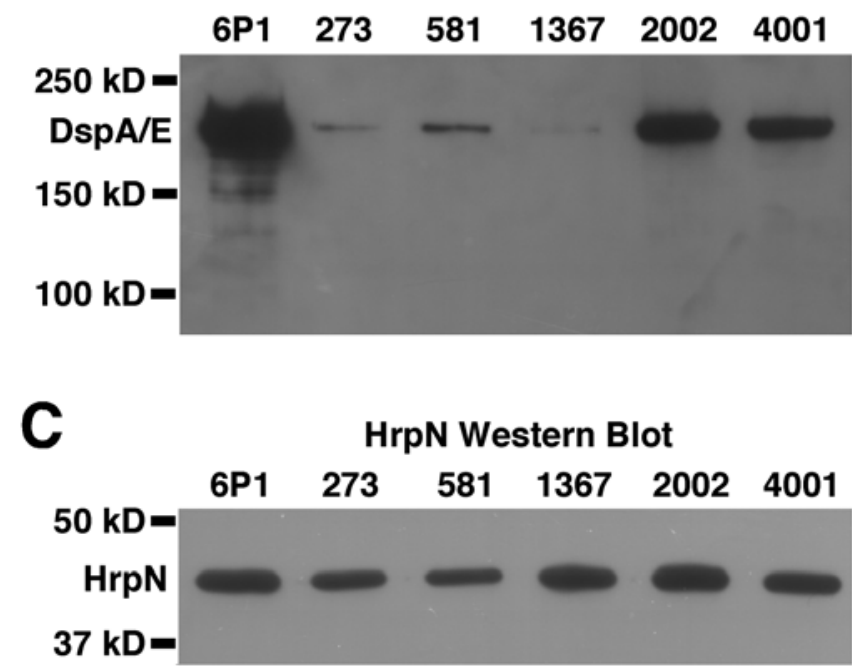

Fig. 9. Comparison of protein secretion by Erwinia amylovora strains HKN06P1, Ea273, Ea581a, CFBP1367, E2002a, and E4001a. Supernatant proteins were collected from E. amylovora strains grown in $h r p$-inducing media at $18^{\circ} \mathrm{C}$ for $26 \mathrm{~h}$. A, Supernatant protein profiles of E. amylovora strains resolved by $12 \%$ sodium dodecyl sulfate polyacrylamide gel electrophoresis and visualized by silver staining. The amount of protein loaded in each lane represented a culture supernatant volume containing $2 \times 10^{9} \mathrm{CFU}$. B, Western blot detection of DspA/E. The amount of protein loaded in each lane represented a culture supernatant volume containing $6 \times 10^{9} \mathrm{CFU}$. C, Western blot detection of HrpN. The amount of protein loaded in each lane represented a culture supernatant volume containing $2 \times 10^{9} \mathrm{CFU}$. 
TABLE 3. Accumulated analysis of variance for a regression relating disease severity on open-pollinated 'Gala' apple seedling to various virulence characteristics

\begin{tabular}{|c|c|c|c|c|c|}
\hline Source ${ }^{a}$ & d.f. & Sum of squares & Mean sum of squares & $\begin{array}{c}\text { Variance ratio } \\
\text { (observed } F \text { value) }\end{array}$ & $\begin{array}{c}\text { Probability } F \geq \\
\text { observed } F \text { value }\end{array}$ \\
\hline Amylovoran & 1 & $2,465.58$ & $2,465.58$ & 28.35 & $<0.001$ \\
\hline Biofilm formation & 1 & 574.04 & 574.04 & 6.60 & 0.018 \\
\hline Growth in host tissue & 1 & $1,918.90$ & $1,918.90$ & 22.07 & $<0.001$ \\
\hline Residual & 20 & $1,739.11$ & 86.96 & $\ldots$ & $\ldots$ \\
\hline Total & 23 & $6,697.62$ & 291.20 & $\ldots$ & $\ldots$ \\
\hline
\end{tabular}

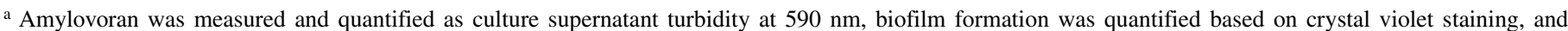
growth in host tissue was expressed as $\mathrm{CFU} \mathrm{g}^{-1}$ in immature apple fruit.

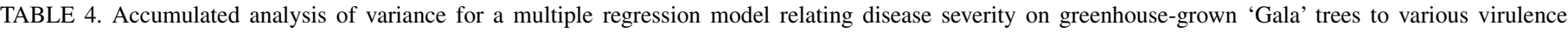
characteristics

\begin{tabular}{|c|c|c|c|c|c|}
\hline Source ${ }^{a}$ & d.f. & Sum of squares & Mean sum of squares & $\begin{array}{c}\text { Variance ratio } \\
\text { (observed } F \text { value) }\end{array}$ & $\begin{array}{l}\text { Probability } F \geq \\
\text { observed } F \text { value }\end{array}$ \\
\hline Growth in host tissue & 1 & $7,193.06$ & $7,193.06$ & 113.14 & $<0.001$ \\
\hline Amylovoran & 1 & 807.91 & 807.91 & 12.71 & $<0.001$ \\
\hline Biofilm formation & 1 & 692.49 & 692.49 & 10.89 & 0.002 \\
\hline Electrolyte leakage & 1 & $1,227.16$ & $1,227.16$ & 19.30 & $<0.001$ \\
\hline Growth rate in sorbitol & 1 & $4,572.56$ & $4,572.56$ & 71.92 & $<0.001$ \\
\hline Residual & 66 & $4,196.13$ & 63.58 & $\ldots$ & $\ldots$ \\
\hline Total & 71 & $18,689.33$ & 263.23 & $\ldots$ & $\cdots$ \\
\hline
\end{tabular}

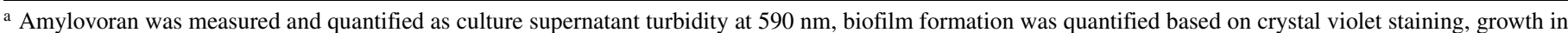
host tissue was expressed as $\mathrm{CFU} \mathrm{\textrm {g } ^ { - 1 }}$ in immature apple fruit, electrolyte leakage was determined by relative ion leakage, and growth rate in sorbitol was determined by linear regression of $\mathrm{CFU} \mathrm{\textrm {ml } ^ { - 1 }}$.

TABLE 5. Summary of results

\begin{tabular}{|c|c|c|c|c|c|c|}
\hline \multirow[b]{2}{*}{ Results } & \multicolumn{6}{|c|}{ Strain $^{\mathrm{a}}$} \\
\hline & HKN06P1 & E2002a & $\mathrm{Ea} 273$ & CFBP1367 & E4001a & Ea581a \\
\hline Disease severity in orchard-grown 'Gala' apple trees & 1 & n.d. & n.d. & n.d. & n.d. & 2 \\
\hline Disease severity in apple seedlings & 1 & n.d. & 1,2 & 2,3 & n.d. & 2,3 \\
\hline Disease severity in 'Gala' trees on own roots & 1 & 2 & n.d. & n.d. & 3 & n.d. \\
\hline Disease severity in greenhouse-grown 'Gala' apple trees & 1 & 2 & 2 & 2 & 2 & 2 \\
\hline Growth in immature apple fruit & 1 & 1 & 2 & 2 & 2 & 2 \\
\hline Incidence in immature apple fruit & Fast & Fast & Medium & Slow & Slow & Slow \\
\hline Biofilm formation & 1 & 1 & 3 & 2,3 & 2 & 3 \\
\hline Amylovoran production & 1 & 2 & 1 & 2 & 1 & 2 \\
\hline Levansucrase activity & 1 & 1 & 1 & 1 & 1 & 1 \\
\hline Growth rate in sucrose & 1 & 1 & 1 & 1 & 2 & 1,2 \\
\hline Growth rate in fructose & 1 & 1 & 1 & 1 & 2 & 1,2 \\
\hline Growth rate in glucose & 1 & 1 & 1 & 1 & 2 & 1,2 \\
\hline Growth rate in sorbitol & 1 & 2 & 3 & 1 & 5 & 4 \\
\hline pEa29 & Yes & Yes & Yes & Yes & Yes & Yes \\
\hline pCPP60 & No & No & Yes & Yes & No & No \\
\hline Electrolyte leakage & 1 & 1,2 & 2 & 4 & 1,2 & 3 \\
\hline DspA/E secretion & High & Medium & Low & Low & Medium & Low \\
\hline HrpN secretion & High & High & Medium & High & High & Medium \\
\hline
\end{tabular}

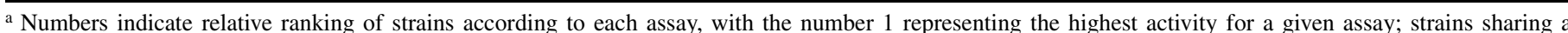
number had no statistically significant difference in activity; n.d. = not done.

E. amylovora strain HKN06P1 produced the greatest disease severity in every virulence assay used in this study (Figs. 1 and 2; Table 5). In fact, in the present study, HKN06P1 was more virulent even than E2002a and E4001a, two exceptionally virulent E. amylovora strains described in the literature $(48,49,51,57)$. HKN06P1 also produced the most rapid disease incidence in immature apple fruit (Fig. 3B). As an example of an exceptionally virulent strain, HKN06P1 could serve as a useful tool for the understanding of the control of E. amylovora virulence. It would be interesting to determine whether the strong virulence of HKN06P1 incurs a fitness cost in the field, or whether strains like HKN06P1 would be expected to dominate the E. amylovora population over time.

\section{ACKNOWLEDGMENTS}

We thank J. Norelli for providing the E. amylovora strains E2002a and E4001a, G. Moorman for suggestions regarding multiple regression analysis, and D. Singh for providing the ungrafted Gala trees. We thank S. V. Beer for providing HrpN and DspA/E antibodies. This work was funded in part by The Pennsylvania State University Plant Pathology Department.

\section{LITERATURE CITED}

1. Afifi, A. A., V. Clark. 2004. Computer-Aided Multivariate Analysis Fourth Edition. Chapman \& Hall/CRC, Boca Raton, FL.

2. Aldridge, P., Metzger, M., and Geider, K. 1997. Genetics of sorbitol metabolism in Erwinia amylovora and its influence on bacterial virulence. Mol. Gen. Genet. 256:611-619.

3. Arthur, J. C. 1885. Proof that bacteria are the direct cause of the disease in trees known as pear blight. Am. Assoc. Adv. Sci. Proc. 34:294-298.

4. Barny, M. A., Guinebretiere, M. H., Marcais, B., Coissac, E., Paulin, J. P., and Laurent, J. 1990. Cloning of a large gene cluster involved in Erwinia amylovora CFBP1430 virulence. Mol. Microbiol. 4:777-786.

5. Bauer, D. W. B., and Steven V. 1991. Further characterization of an $h r p$ gene cluster of Erwinia amylovora. Mol. Plant-Microbe Interact. 4:493499 . 
6. Bellemann, P., Bereswill, S., Berger, S., and Geider, K. 1994. Visualization of capsule formation by Erwinia amylovora and assays to determine amylovoran synthesis. Int. J. Biol. Macromol. 16:290-296.

7. Bellemann, P., and Geider, K. 1992. Localization of transposon insertions in pathogenicity mutants of Erwinia amylovora and their biochemical characterization. J. Gen. Microbiol. 138:931-940.

8. Bennett, R. A. and Billing, E. 1978. Capsulation and virulence in Erwinia amylovora. Ann. Appl. Biol. 89:41-45.

9. Bereswill, S., and Geider, K. 1997. Characterization of the rcsB gene from Erwinia amylovora and its influence on exoploysaccharide synthesis and virulence of the fire blight pathogen. J. Bacteriol. 179:1354-1361.

10. Bereswill, S., Pahl, A., Bellemann, P., Zeller, W., and Geider, K. 1992. Sensitive and species-specific detection of Erwinia amylovora by polymerase chain reaction analysis. Appl. Environ. Microbiol. 58:35223526.

11. Bernhard, F., Coplin, D. L., and Geider, K. 1993. A gene cluster for amylovoran synthesis in Erwinia amylovora: Characterization and relationship to cps genes in Erwinia stewartii. Mol. Gen. Genet. 239:158-168.

12. Billing, E., Baker, L. A. E., Crosse, J. E. and Garrett, C. M. E. 1961. Characteristics of English Isolates of Erwinia amylovora (burrill) Winslow et al. J. Appl.Bacteriol. 24:195-211.

13. Bocsanczy, A. M., Nissinen, R. M., Oh, C. S., and Beer, S. V. 2008. HrpN of Erwinia amylovora functions in the translocation of DspA/E into plant cells. Mol. Plant Pathol. 9:425-434.

14. Bogdanove, A. J., Bauer, D. W., and Beer, S. V. 1998. Erwinia amylovora secretes DspE, a pathogenicity factor and functional AvrE homolog, through the Hrp (type III secretion) pathway. J. Bacteriol. 180:2244-2247.

15. Bogs, J., and Geider, K. 2000. Molecular analysis of sucrose metabolism of Erwinia amylovora and influence on bacterial virulence. J. Bacteriol. 182:5351-5358.

16. Braun, P. G., and Hildebrand, P. D. 2005. Infection, carbohydrate utilization, and protein profiles of apple, pear, and raspberry isolates of Erwinia amylovora. Can. J. Plant Pathol. Rev. Can. Phytopathol. 27:338346.

17. Burrill, T. J. 1880. Anthrax of fruit trees; or the so-called fire blight of pear, and twig blight of apple trees. Am. Assoc. Adv. Sci. Proc. 29:583597.

18. Cabrefiga, J., and Montesinos, E. 2005. Analysis of aggressiveness of Erwinia amylovora using disease-dose and time relationships. Phytopathology 95:1430-1437

19. Chong, C., and Taper, C. D. 1971. Daily variation of sorbitol and related carbohydrates in Malus leaves. Can. J. Bot. 49:173-177.

20. DebRoy, S., Thilmony, R., Kwack, Y. B., Nomura, K., and He, S. Y. 2004. A family of conserved bacterial effectors inhibits salicylic acid-mediated basal immunity and promotes disease necrosis in plants. Proc. Natl. Acad. Sci. USA 101:9927-9932.

21. Degrave, A., Fagard, M., Perino, C., Brisset, M. N., Gaubert, S., Laroche, S., Patrit, O., and Barny, M. A. 2008. Erwinia amylovora type threesecreted proteins trigger cell death and defense responses in Arabidopsis thaliana. Mol. Plant-Microbe Interact. 21:1076-1086.

22. Denning, W. 1794. On the decay of apple trees. Trans. Soc. Promotion Agric. Arts Manufact. Inst. State N. Y 1:219-222.

23. Eastgate, J. A. 2000. Erwinia amylovora: The molecular basis of fireblight disease. Mol. Plant Pathol. 1:325-329.

24. Falkenstein, H., Bellemann, P., Walter, S., Zeller, W., and Geider, K. 1988. Identification of Erwinia amylovora, the fireblight pathogen, by colony hybridization with DNA from plasmid pEA29. Appl. Environ. Microbiol. 54:2798-2802.

25. Falkenstein, H., Zeller, W., and Geider, K. 1989. The 29 kb plasmid common in strains of Erwinia amylovora modulates development of fireblight symptoms. J. Gen. Microbiol. 135:2643-2650.

26. Gaudriault, S., Brisset, M. N., and Barny, M. A. 1998. HrpW of Erwinia amylovora, a new Hrp-secreted protein. FEBS Lett. 428:224-228.

27. Gaudriault, S., Malandrin, L., Paulin, J. P., and Barny, M. A. 1997. DspA, an essential pathogenicity factor of Erwinia amylovora showing homology with AvrE of Pseudomonas syringae, is secreted via the Hrp secretion pathway in a DspB-dependent way. Mol. Microbiol. 26:1057-1069.

28. Geider, K. 2000. Exopolysaccharides of Erwinia amylovora: Structure, biosynthesis, regulation, role in pathogenicity of amylovoran and levan. Pages 117-140 in: Fire Blight: The Disease and its Causative Agent, Erwinia amylovora. J. L. Vanneste, ed. CAB International, Wallingford, UK.

29. Goszczynska, T., and Serfontein, J. J. 2000. Introduction to Practical Phytobacteriology - A Manual for Phytobacteriology. Ultra Litho (Pty) Ltd., Heriotdale, Johannesburg, South Africa.

30. Ham, J. H., Bauer, D. W., Fouts, D. E., and Collmer, A. 1998. A cloned Erwinia chrysanthemi Hrp (type III protein secretion) system functions in Escherichia coli to deliver Pseudomonas syringae Avr signals to plant cells and to secrete Avr proteins in culture. Proc. Natl. Acad. Sci. USA 95:10206-10211.
31. Huynh, T. V., Dahlbeck, D., and Staskawicz, B. J. 1989. Bacterial blight of soybean-regulation of a pathogen gene determining host cultivar specificity. Science 245:1374-1377.

32. Jensen, P. J., Rytter, J., Detwiler, E. A., Travis, J. W., and McNellis, T. W. 2003. Rootstock effects on gene expression patterns in apple tree scions. Plant Mol. Biol. 53:493-511.

33. Johnson, K. B., and Stockwell, V. O. 1998. Management of fire blight: A case study in microbial ecology. Annu. Rev. Phytopathol. 36:227-248.

34. Jones, A. L., and Geider, K. 2001. Erwinia amylovora group. Pages 40-54 in: Laboratory Guide for Identification of Plant Pathogenic Bacteria. N. W. J. Schaad and J. B. Chun, eds. American Phytopathological Society Press, St. Paul, MN.

35. Kim, J. F., Wei, Z. M., and Beer, S. V. 1997. The hrpA and hrpC operons of Erwinia amylovora encode components of a type III pathway that secretes harpin. J. Bacteriol. 179:1690-1697.

36. Koczan, J. M., McGrath, M. J., Zhao, Y., and Sundin, G. W. 2009. Contribution of Erwinia amylovora exopolysaccharides amylovoran and levan to biofilm formation: Implications in pathogenicity. Phytopathology 99:1237-1244

37. Komagata, K., Tamaga, Y., and Kocur, M. 1968. Differentiation of Erwinia amylovora, Erwinia carotovora and Erwinia herbicola. J. Gen. Appl. Microbiol. 14:39-45.

38. Laemmli, U. K. 1970. Cleavage of structural proteins during assembly of head of bacteriophage-T4. Nature 227:680-685.

39. Laurent, J., Barny, M.-A., Kotoujansky, A., Dufriche, P., and Vanneste, J. L. 1989. Characterization of a ubiquitous plasmid in Erwinia amylovora. Mol. Plant-Microbe Interact. 2:160-164.

40. Lelliott, R. A., and Dickey, R. S. 1984. Genus VII. Erwinia. In: Bergey's Manual of Systematic Bacteriology. Volume Two, The Proteobacteria N. R. K. D. J. Brenner and J. T. Staley, eds. Springer, New York.

41. Llop, P., Donat, V., Rodriguez, M., Cabrefiga, J., Ruz, L., Palomo, J. L., Montesinos, E., and Lopez, M. M. 2006. An indigenous virulent strain of Erwinia amylovora lacking the ubiquitous plasmid pEA29. Phytopathology 96:900-907.

42. Madden, L. V. H., and van den Bosch, G. 2007. The Study of Plant Disease Epidemics. American Phytopathological Society, St. Paul, MN.

43. McGhee, G. C., and Jones, A. L. 2000. Complete nucleotide sequence of ubiquitous plasmid pEA29 from Erwinia amylovora strain Ea88: Gene organization and intraspecies variation. Appl. Environ. Microbiol. 66:4897-4907

44. McManus, P. S., and Jones, A. L. 1995. Genetic fingerprinting of Erwinia amylovora strains isolated from tree-fruit crops and Rubus spp. Phytopathology 85:1547-1553.

45. Momol, E. A., and Aldwinckle, H. S. 2000. Genetic diversity and host range of Erwinia amylovora. Pages 55-72 in: Fire Blight: The Disease and Its Causative Agent, Erwinia amylovora. J. L. Vanneste, ed. CAB International, Wallingford, UK.

46. Momol, M. T., Momol, E. A., Lamboy, W. F., Norelli, J. L., Beer, S. V. and Aldwinckle, H. S. 1997. Characterization of Erwinia amylovora strains using random amplified polymorphic DNA fragments (RAPDs). J. Appl. Microbiol. 82:389-398.

47. Nissinen, R. M., Ytterberg, A. J., Bogdanove, A. J., Van Wijk, K. J., and Beer, S. V. 2007. Analyses of the secretomes of Erwinia amylovora and selected hrp mutants reveal novel type III secreted proteins and an effect of HrpJ on extracellular harpin levels. Mol. Plant Pathol. 8:55-67.

48. Norelli, J. L., and Aldwinckle, H. S. 1986. Differential susceptibility of Malus spp. cultivars Robusta 5, Novole, and Ottawa 523 to Erwinia amylovora. Plant Dis. 70:1017-1019.

49. Norelli, J. L., Aldwinckle, H. S., and Beer, S. V. 1984. Differential host $\times$ pathogen interactions among cultivars of apple and strains of Erwinia amylovora. Phytopathology 74:136-139.

50. Norelli, J. L., Aldwinckle, H. S., and Beer, S. V. 1988. Virulence of Erwinia amylovora strains to Malus sp. Novole plants grown in vitro and in greenhouse. Phytopathology 78:1292-1297.

51. Norelli, J. L., Holleran, H. T., Johnson, W. C., Robinson, T. L., and Aldwinckle, H. S. 2003. Resistance of Geneva and other apple rootstocks to Erwinia amylovora. Plant Dis. 87:26-32.

52. Norelli, J. L., Jones, A. L., and Aldwinckle, H. S. 2003. Fire blight management in the twenty-first century-using new technologies that enhance host resistance in apple. Plant Dis. 87:756-765.

53. Oh, C. S., Martin, G. B., and Beer, S. V. 2007. DspA/E, a type III effector of Erwinia amylovora, is required for early rapid growth in Nicotiana benthamiana and causes NbSGT1-dependent cell death. Mol. Plant Pathol. 8:255-265.

54. Oh, C.-S. B., and Steven, V. 2005. Molecular genetics of Erwinia amylovora involved in the development of fire blight FEMS Microbiol. Lett. 253:185-192.

55. O'Toole, G. A. P., Watnick, L. A., Newman, P. I., Weaver, D. K., and Kolter, V. B. 1999. Genetic approaches to study of biofilms. Pages 91-109 in: Methods in Enzymology, M. I. S. John N. Abelson and Ron J. Doyle, 
eds. Academic Press, San Diego, CA.

56. Psallidas, P., and Tsiantos, J. 2000. Chemical control of fire blight. Page 370 in: Fire Blight: The Disease and Its Causative Agent, Erwinia amylovora. J. L. Vanneste, ed. CABI, Wallingford, Oxon, UK and New York.

57. Quamme, H. A., and Bonn, W. G. 1981. Virulence of Erwinia amylovora and its influence on the determination of fire blight resistance of pear cultivars and seedlings. Can. J. Plant Pathol. 3:187-190.

58. Sambrook, J. R., and D. W., eds. 2001. Molecular Cloning: A Laboratory Manual. Cold Spring Harbor Laboratory Press, Cold Spring Harbor, NY.

59. Schroth, M. N., Thomson, S. V., Hildebrand, D. C., and Moller, W. J. 1974. Epidemiology and control of fire blight. Annu. Rev. Phytopathol. 12:389-412.

60. Shaner, G., Stromberg, E. L., Lacy, G. H., Barker, K. R., and Pirone, T. P. 1992. Nomenclature and concepts of pathogenicity and virulence. Annu. Rev. Phytopathol. 30:47-66.

61. Sinn, J. P., Oh, C. S., Jensen, P. J., Carpenter, S. C. D., Beer, S. V., and McNellis, T. W. 2008. The C-terminal half of the HrpN virulence protein of the fire blight pathogen Erwinia amylovora is essential for its secretion and for its virulence and avirulence activities. Mol. Plant-Microbe Interact. 21:1387-1397.

62. Steinberger, E. M., Cheng, G. Y., and Beer, S. V. 1990. Characterization of a 56-kb plasmid of Erwinia amylovora Ea322: Its noninvolvement in pathogenicity. Plasmid 24:12-24.

63. Steinberger, E. M., and Beer, S. V. 1988. Creation and complementation of pathogenicity mutants of Erwinia amylovora. Mol. Plant-Microbe Interact. 1:135-144.

64. van der Zwet, T., and Keil, H. L. 1979. Fire blight: A bacterial disease of Rosaceous plants. United States Department of Agriculture.

65. Vanneste, J. L. 2000. What is fireblight? Who is Erwinia amylovora? How to control it? Pages 1-6 in: Fire Blight: The Disease and Its Causative Agent, Erwinia amylovora. J. L. Vanneste, ed. CAB International, Wallingford, UK.

66. Wallaart, R. A. M. 1980. Distribution of sorbitol in Rosaceace. Phytochemistry 19:2603-2610.

67. Wei, Z. M., Sneath, B. J., and Beer, S. V. 1992. Expression of Erwinia amylovora hrp genes in response to environmental stimuli. J. Bacteriol. 174:1875-1882.

68. Zhang, Y., and Geider, K. 1997. Differentiation of Erwinia amylovora strains by pulsed-field gel electrophoresis. Appl. Environ. Microbiol. 63:4421-4426.

69. Zhao, Y., He, S. Y., and Sundin, G. W. 2006. The Erwinia amylovora avrRpt2EA gene contributes to virulence on pear and AvrRpt2EA is recognized by Arabidopsis RPS2 when expressed in Pseudomonas syringae. Mol. Plant-Microbe Interact. 19:644-654. 